\title{
THE POLAND-UNITED STATES SECURITY RELATIONS IN THE LIGHT OF ASYMMETRY THEORY
}

Asymmetry in inter-state relations occurs when, resulting from a unique confluence of power factors, one of the partners enjoys more freedom of action than the other, thus obtaining a dominant position. Various theoretical propositions remain unequivocal, as to the ways how effectively the power factors can be applied to exert influence on a partner state that holds an inferior position. Still, in the process, the superior power does both incur costs and risks ineffectiveness, therefore having to precisely calculate its modus operandi. At the same time, the weaker state has at its disposal certain means useful in managing the consequences of existing power discrepancies. In fact, all aspects, each little business involved in the relation with a dominant partner, is in proportion a larger issue for the weaker side than for the stronger one. This fosters mobilization and attentiveness.

Scholars searching for systemic interdependence related to such situations in international relations argue about the actual effects of asymmetry. The only thing they do agree on is that the dominant side has, in theory, a wider spectrum of options and tools to leverage the situation. There is however no agreement about whether it critically determines the nature of international relations. Undeniably, asymmetry evokes very negative conceptual and psychological connotations, since one perceives asymmetry as a disturbance of what is viewed as its polar opposite, and what is identified as the ideal, normal state of affairs. That impacts heavily, both cognitively and emotionally, the scientific discourse on foreign policy, and, in a broader context, international relations. However, in theory, asymmetry can take various denotations, making it harder for us to evaluate such relations via simple application of a zero-sum game of better (symmetrical) vs. worse (asymmetrical). That is in no way a simple and clear-cut division.

Asymmetry can be called a structural feature of Polish-US relations, manifesting itself with full strength in the field of security and defense (Szklarski, 2015: 22). This seems rather self-evident, given the classical determinants of power and, what follows, the discrepancies in the two countries' potentials, different roles played in international relations and the position of the USA as the guarantor of Poland's security. That fact allows shifting the analytical focus more to the realm of what is its result, including the dynamics of mutual relations pursued in the shadow of their obvious characteristics. In the process, the benefits of both partners may vary, but the durability of their relations depends on their end state, or mutual expectations as to what such an end state should look like. One can actually conceptualize these relations as a long-term phenomenon, and see them as a product of a complex process, rather than just the result of a simple 
one-to-one relation stemming from supremacy or power deficit. Their reality - the here and now, has the same bearing as the political maturity of the partners and public perception (affirmation or refusal) of the state of affairs.

\section{ASYMMETRY THEORY IN THE MAKING}

Asymmetry as a lasting feature of international relations, or a characteristic of relations between states representing significantly different potentials, has been for decades researched by scholars representing various sub-disciplines of strategic studies (Dolan et. al., 1980: 415-449, Dolan, Tomlin, 1984: 349-368). Their common conclusion pointed to the pivotal meaning of asymmetry as a research field in foreign policy studies. The "alliance theory" has also been a graceful subject-matter to delve into (Dybczyński, 2014; Wight, 1978). It offers a number of observations of state behavior in asymmetrical security relations. These theories are also used as research tools, among others, in regional studies (when explaining international conduct of a given state), economic studies (in regard to access to information, market share and impact on decision-making), diplomacy (for example, in searching for the methods of leveling the negotiating positions of asymmetrical parties), or in the theory of international relations. At the confluence of various disciplines, we are currently observing the development of a specific study area, that is directly and closely connected to this particular, individual feature of international relations. It has even been termed, maybe a bit prematurely, "the asymmetry theory".

Meanwhile, it doesn't actually propose a coherent theory, rooted in the scientific analysis of the differences in national potentials and manifestations of their effects in the field of international relations. Instead, the "asymmetry theory" offers a revisionist interpretation of existing international relations theories and adds to it a unique set of preliminary findings specific for its research areas. They do not fall, however into the trap of fetishization of the sources of power. On the contrary, these findings highlight the difficulties connected with using asymmetry as a simple tool of influence. On the other hand, they don't overemphasize the possibilities of balancing the power disparities, recognizing that the outcomes depend heavily on situational contexts and available options. Such research efforts surely deserve a follow-up in order to better understand patterns of asymmetrical relations between sovereign states and the impulses for their behavior, whether in position of weakness or dominance. As bilateral relations are the natural research environment here, and so the specific characteristics of concrete cases, the topical studies dig into some universal conclusions regarding the structure of (asymmetrical) international relations.

The modern scientific point of reference in the "asymmetry theory" has been offered by Brantly Womack's regional research of Southern and Eastern Asia at the University of Virginia (Womack, 2001, 2003, 2004, 2006, 2010). According to him, asymmetrical inter-state relations (researched from the perspective of all actors) not only concern managing the natural consequences of disparity in national potentials, but also divergent perceptions of international matters. Paradoxically, this can form a solid basis for stability by raising the predictability of state's behavior operating in such an environment. Womack's research does not neglect the value of a well-balanced cooper- 
ation or the regulatory role of international law. However, his starting point is the hypothesis that there exists a paradoxical equilibrium between the two partners who hold unequal international status and national potential, defining their mutual relation in a changing environment. As a result, Womack is treating asymmetry as a feature of international relations without any clean determinants producing one-dimensional effects in a relationship defined by hegemony vs. subordinance. The possible outcome of such a relation is constructed upon a peculiar dynamic combination of the established interplay, where both sides, acting in the fear of losing their leeway, de facto do cooperate.

The stakes are clearly different for the partners and, consequently, their motivations of constructive behavior. The weaker side, for example, looks to compensate its own frailty while the stronger one seeks increased international legitimization of its actions. The only true effect stemming directly from the difference in potentials is the one that the stronger power is able to (mechanically) wield more influence on the weaker one, than the other way round and that the inferior state has to be more cautious, more attentive and observant of the stronger partner's actions. Nonetheless, this is not going to lead to a situation when the dominant side can effectively exercise full control of the policies of the weaker one, nor that the latter precisely reads the hegemon's intentions, and consequently is more inclined to co-operate.

The problem here can be very complex in nature, and strongly determined by the international context. It could look bad if the stronger side tried to disregard the weaker one (as posing no threat or having a limited significance in searching for the solutions of international problems). It would be different, if the latter overvalued its own co-operative stance, or the actions of a dominating power, in search for direct profits while being fully conscious of its own higher stake in such relations. The stronger side simply enjoys more alternatives in the conduct of its international activities. That is why the weaker of the two must always be prepared for a sudden turnaround, policy shift or attitude change of the stronger partner. Such a change yields a much more serious, proportionate impact to the weaker side. Nevertheless its reaction has to be very well thought through, mature and aimed at minimizing possible risks of a permanent deterioration of the relation.

It can also look for ways of reducing the consequences of such a policy shift, for example by directly influencing the hegemon's decision-makers or public opinion, using the opportunities created by its political system. The open and largely transparent system of the United States offers a lot to their foreign partners in that regard, by means of ethnic or interest-based lobbying. It can be professionally endowed with advocacy services commercially available from the free market. Its effectiveness in the foreign policy field might be disputable, but it offers weaker partners perfectly legal means of influencing (shaping) US decisions, especially in the early phases of the process. Under certain circumstances, the weaker side can also buy the attributes of power, create alliances with other nations who felt the impact of the described policy shift (or are unwilling to allow such a shift), or enter some interaction with an international actor whose interests are at odds with the disloyal hegemon. It can also tie it up by multilateral agreements that provide mechanisms for troubleshooting the disagreements and negotiating reciprocal benefits. Such a situation has been largely characteristic for the Trans-Atlantic relations, leading inter alia to NATO's formation, based on legally binding, US secu- 
rity guarantees for Europe and later-on to the profound institutionalization of the organization and regulation of mutual rights and responsibilities of its member-states.

Managing asymmetrical relations requires avoiding (conscious, in other words those resulting from the stronger side's negligence, or the emotions of the weaker side) any persistent problems in the cooperation of the two sides, or - the opposite - developing lasting mechanisms, designed at drawing the positions of the two states closer together. In that last matter, the periodically recurring "pragmatism" of the US policy, manifesting itself in avoiding symbolism and gestures so meaningful to the smaller partners, scarcity of high-level foreign visits or the reduction in the number of visited nations - have not always served the above purpose. That mode of behavior limits the positive potential of direct dialogue as a stabilizing tool of in US foreign policy. Such situations can easily lead to certain misinterpretations of Washington's policies or their intentions by the weaker partners and cause confusion and uncertainty along with some substantial consequences. And I do not mean here a simple repetition of foreign policy rituals or underinvested personal relations of the national leaders, void of substance, but rather a productive, symbolic and practical highlighting of the continued relationship. Such things not only eventually lead to concrete political and practical effects, but also contain a lot of bridge-building potential. After all, the indicator of the seriousness and closeness of the relationship is the extent to which the other side is able to coolly and maturely (strategically) interpret American intentions and move smoothly through dry patches in bilateral relations.

A bigger partner holds greater responsibility for building and maintaining platforms for common interest and using the language of dialogue that stresses the unity of purpose and benefits, while the smaller one will likely suffer more damage caused by its possible negligence in that matter. This also concerns the development of the architecture of mutual relations, both on the working and political level, and time-management in the foreign policy field. In the case of the United States, their time for international partners, naturally limited by domestic priorities, has to be further divided between managing global issues, and maintaining bilateral relations. As a result, each and every one of the smaller partners has to fight for their time-slot in the attention of the hegemon. In the background of strategic relations, there remain a lot of areas of mutual engagements, possibly raising the quality, and improving the symmetry of asymmetrical relations, like intercultural exchanges, economic ties, or scholarship programs. In Polish-US relations, the most vivid and unquestionable impediment for building and using all those opportunities is the visa regime asymmetry. Poland has unilaterally waived the visa requirement for American citizens over two decades ago and has been waiting for a reciprocal action from Washington ever since. The inadequacy in consideration for the other partner, and the social fabric of mutual relations, could in the long run, deepen the consequences of asymmetry, with added layers of frustration, misunderstanding, indifference, or simply ignorance.

\section{ASYMMETRY IN POLISH-US RELATIONS IN THE SECURITY FIELD}

The asymmetry theory prompts that the weaker partner does not necessarily always have to follow the expectations of the stronger party. As I mentioned earlier, it has at its 
disposal some instruments useful in shaping these expectations. From the other perspective, the stronger partner doesn't always need or is able to make use of all its sources and attributes of international advantage. Such a situation is characteristic for the Polish-US security and defense relations. Except for certain unique circumstances or simplified systemic characteristics of these relations (according to the model composed of benevolent hegemon and a loyal ally), it is dictated by a few concrete lasting factors. These include: both nations being a part of the democratic West, attachment to similar standards of international behavior and common system of values. That facilitates mutual communication and increases trust put into understanding intentions or possible consequences of each other's actions. Sovereignty, as the basic criterion of their international status, protected by the law, implies certain restraints in applying the sources of power over the decisions of the other member of international community. Nations, by nature and history, differ in the amount and type of power they possess, as well as the corresponding ability to influence international politics. Still, they are similar in the set rights and obligations. A principle of one state - one vote, in multilateral relations sometimes eased out by the rule of weighted voting, or the consensus rule, formally balances inter-state relations in decision-making processes.

Membership in the same international institutions, and the defense alliance - North Atlantic Treaty Organization - has broadened the platform for interaction and created beneficial and practical standards of behavior that can facilitate mutual cooperation, such as, permanent intra-alliance consultations, as a primary tool in managing allied co-operation. And a practical instrument that portrays the concrete benefits that it bears is, for example a NATO Status of Force (SOFA) agreement, offering a common point of reference and legal standard for member states' military cooperation. The disparity of institutional links (especially when it favors the weaker), can introduce additional tensions and complications into that relationship. In case of Polish-US relations, such a role is being played by the European Union. It is within that framework that we observe a substantial interconnectedness of various levels of cooperation among the member states, representing a complex source of informal political pressure. In a formal aspect, it imposes a number of standard forms of behavior affecting the bilateral cooperation between the EU members with non-member states. That especially pertains to the economic and trade matters based on a common European Law (although there exist some legal exceptions, for example concerning defense procurement). A separate issue in this context is the separate set of norms resulting directly from the UE-US relations. They also affect the realm of bilateral cooperation.

Factors that specifically shape the asymmetry in Polish-US relations can also be found in the very nature of the two state systems. In the first case, it is the openness of all of the subsequent Polish democratic governments for strengthening their cooperation with America. What goes with it is the relative ease in communication with the decision-making centers in Poland and their political instinct (assessment of the country's best interest) suggesting a serious consideration of the arguments put forward by the partner (without predetermining the decision). One should also add a rather solid and constant, though varying in time and strength, popular acceptance (pro-Americanism, or instinctive pro-Atlanticism) of this foreign policy course for Poland (Zaborowski, Longhurst, 2003). 
Being a member of the North Atlantic Treaty Organization has been extremely important for bringing security guarantees, augmenting Polish defence, but also as a treaty-based mechanism of mutual (collective) defense of the USA and Europe. Warsaw's recognition and attachment to the international law regulations has been a relatively important factor too, as it can narrow down the effects of asymmetric relations and add rules to the multilateral co-operation where Poland, a mid-size power, enjoys a rather safe position in the decision-making processes.

On the US side, one must highlight the pluralism of the political system. In the decision-making process, it allows for the influence and argumentation provided by various interest groups. Since that system naturally involves the domestic actors, it does also allow for a foreign participation in the process. Apart from standard, but also ad hoc international contacts, they have specialized and highly professional lobbying instruments at their disposal. They are not only legal and quite transparent, but also extremely broad and liberal in the scope of provided services. What's more, they hide behind some more refined names, like political advocacy or political consulting, or behind their business-connected segments, like economics or media. These systemic features, by definition, make the American decision-making process - at least theoretically - consider a much wider spectrum of goals than just the one formulated by the US Government. Through this self-imposed pluralism, the United States provide not only for a broader representation of interests reflected in its foreign policy decisions and thus its stronger legitimization, but also for managing asymmetry in its relations with other nations.

On the other hand, such an openness in the policy-shaping process tends to get narrowed down at the time of actual decisions. Over the recent two decades American defense policy has been thrown around by a few contradictory tendencies. With the basic assumption that it requires working with the allies wherever and whenever possible, but also finds room for individual action when necessary, it has long shown a strong preference for taking-over the initiative and reducing consultations with foreign partners. It refers to a specific type of systemic behavior (similar in style to Clinton's multilateralism, Bush's unilateralism, or Obama's leadership by example), and not to the analysis of its specific models and validations. What motivates it is the permanent conviction that it helps with the gearing of the cooperation, and pulling the partners away from searching for alternative solutions (potentially detrimental to American interests). The preference for unilateralism is also forced by the commonly shared conviction among the US leadership, that the allies are slow and reluctant when deciding on the involvement, so they should be gently pushed towards these more decisive steps. But, in the background, there has always been a readiness for individual, independent action as a faster and more effective method than slow and largely ineffective multilateral decision-making. In its 2003 State of the Union Address President G. W. Bush put it in very precise terms: America's purpose is more than to follow a process. It is to achieve a result (Bush, 2003).

Still, even when looking at things from that perspective, allies remain important to America. Even if they proved unable or unwilling (or both) at the time of need, and one couldn't count on their full support - the US engagement did always raise the likelihood of productive co-operation. If not just to obtain the desired results, then at least to man- 
age the consequences of the US unilateral actions. The stake remained, namely retaining the influence that allies have on these developments or managing the differences in relations with Washington. The recent years' experience of Iraq and Afghanistan seem to fall into that pattern. The classic feature of asymmetric American leadership has been its execution in a way that allows for avoiding long-lasting bitterness in relations with partners and increases legitimization of US policies. That concerns for instance, some implications of the US military interventionism, legitimized domestically, but not necessarily to the same extent by its allies and partners.

The manifestation of that approach is also visible in the presupposition of the USA's natural leadership in multinational cooperation. In 2007, the very same President G. W. Bush said: "American foreign policy is more than a matter of war and diplomacy. Our work in the world is also based on a timeless truth: to whom much is given, much is required" (Bush, 2007). The model of US global leadership evolved in time during the Obama Presidency, fostering the accusations of leading from behind or even a reluctant leadership. This motive, as it is potentially persistent in American foreign policy, holds its importance for future developments (also as a research area). It can take the form of selective American engagement (limited to a region or to a particular international problem), more or less active enabling support for the actions of allies, with a larger aim of giving them the task of carrying out costly human undertakings and applying its own technological and military advantage, or yet other mutations of the above described options. We can almost certainly reject some more radical scenarios of the US policy limitations (neo-isolationistic). The same can be said about the significance of the multilateral co-operation fora, as it is the USA that will be shaping them according to their own needs and limiting to a minimum the transactional costs. In relation to international norms, this can also be applied to such ways of establishing the rules of cooperation that would support the vital interests of the United States and, wherever it may seem justified, they wouldn't limit in any way the option for military involvement (NATO Allied Force operation in Kosovo, the operation in Iraq).

Table 1

Selected Sources of National Power (2015)

\begin{tabular}{||l|r|r||}
\hline & Poland & USA \\
\hline \multicolumn{1}{|c|}{1} & 2 & \multicolumn{1}{c||}{3} \\
\hline Population (million) & 38.483 & 320.087 \\
\hline Area (sq. km) & 312,679 & $9,147,400$ \\
\hline GDP (USD billion) & 544.746 & $17,528.380$ \\
\hline GDP per capita (USD) & 14,135 & 54,980 \\
\hline Economic Innovation ${ }^{1}$ (global position) & 45 & 6 \\
\hline Research and development funds (USD billion) & 6.2 & 396.7 \\
\hline
\end{tabular}

1 Global Innovation Index - ranking of world economies' innovation capabilities prepared by Johnson Cornell University, Institut Européen d'Administration des Affaires (INSEAD) and World Intellectual Property Organization. 


\begin{tabular}{||l|c|c||}
\hline \multicolumn{1}{|c|}{1} & 2 & 3 \\
\hline Where to be born index ${ }^{2}$ (global position) & 33 & 16 \\
\hline Military expenditures (USD billion) & 8.5 & 628.8 \\
\hline Military potential (global position) & 18 & 1 \\
\hline \hline
\end{tabular}

Source: Multiple sources, compiled by R. Kupiecki.

The asymmetry in Polish-US security relations can be analyzed as a multi-layered construction.

\section{EXPECTATIONS AND REALITIES}

The first of them stems from a huge discrepancy of the two states in potentials, international position and power to create international facts: political, military, economic and technological. What follows is the difference in expectations regarding mutual security commitments. Over the last 25 years the bilateral security connections evolved significantly. They have reached the level of asymmetrical partnership based on mutually attractive calculation of direct and proxy costs and benefits. The United States remain for Poland the most important force multiplier and guarantor of its security. The current 2014 National Security Strategy of Poland lists the United States, together with NATO and the EU, as a solid pillar of its security. It also calls for keeping credible US security guarantees for Europe, including the largest possible presence of American troops on this side of the pond (National, 2014: 6, 12, 34, 40, 67, 71). In America, the numerous US political declarations stress the uniqueness of this bilateral relation. In his June 4, 2014 Warsaw speech, President Obama called "Poland one of our strongest and closest allies". He also repeated his assurances of American security guarantees (Obama, 2014). Thus, the mutual relation is called by both capitals a strategic partnership. However, it is worth noting that Washington extends that term to its relations with several dozen other countries in the world.

In the eyes of US leaders, since the post-communist transformation Poland changed its international role from a state-in-need and former recipient of US financial assistance, to a partner bound by community of values, that is able to contribute its military power and resources to the cause of international conflict resolution, adding to the US-controlled instruments of its global agenda. What follows is the natural expectation that, when necessary, it will manifest itself in concrete material terms. But there remains a realm of vagueness as to unspecified short-term benefits for Poland resulting from the nation's involvement in US policies, or the potential political consequences resulting from a possible failure to act. An illustration for that can be the public debates on Polish Armed Forces' involvement in Iraq, the strengthening of Polish defense sys-

2 Where to be born index - prepared and published annually by The Economist Intelligence Unit, the variables include among others: effectiveness of health system, climate, job security, taxation system, crime level. 
tems with American involvement and military equipment transfer or 2007-2008 negotiations concerning the deployment of a US missile defense system to Poland.

This role-changing moment can be traced back to the year 1999 and Poland joining NATO (Osica, 2009: 122-138). The constant dilemma of extremely delicate nature looming in the background concerns the question of common action, driven either by pure idealism and the set of common values, or motivated transactionally and expecting maximization of quick profits at a minimum of costs. A factor that does not bring much help in reaching the decision is the assessment of common interests that can be viewed differently on both sides. What's more, on the side of the USA - the largest economy in the world, the biggest military power and the third most populated country in the world, viewing everything from the perspective of its global agenda, the interests of a smaller partner, or even of a whole region, can be more or less consciously ignored or measured against American interest. That issue seems to be of rather permanent nature, and occasionally challenges Polish-American relations.

The scale and scope of the problem stemming from asymmetry in Polish-US relations is largely determined by the dynamically changing American policy priorities in Central and Eastern Europe. While this policy has undergone numerous twists in the last two decades, there has still been a visible tendency to systematically narrow down the scope of focus of US foreign policy related to that region. There has certainly been a certain impact caused by a 1999, or more precisely: 1999-2004 caesura, in Polish-American relations, in strategic terms understood in Poland only a few years later. The enthusiasm and the energy of the initial years of Poland's membership in NATO and the closeness of its security relations formed at that time with the US, yielded natural expectations that these bonds would be systematically strengthened and translate themselves to a larger American military presence and contribution to the security of Poland, and more broadly the whole of Central Europe. Meanwhile, for the United States, the meaning of the first post-Cold War NATO enlargement was rather simple. It meant mission accomplished and the silent end of democracy consolidation in that region. The Central European allies were relocated from the position of incumbents of US security assistance (with the Article 5. of the Washington Treaty guarantees remaining valid), to the category of providers in the global stabilization processes.

This meant in practical terms no real desire on the US side to compensate the net value of the military and material effort incurred by their allies, by means of a noticeable increase of their national security, that would go any further than readiness to facilitate the in-theatre operability of their forces within joint multinational operations. The Pentagon had been always ready to support logistically allied forces to the extent dictated by local operational needs. They functioned in the larger context of American foreign policy objectives focused at fostering allied participation in US military actions. That was also justified by the logic of the coherence of military operations (a single network enabling military capabilities), where allied efforts could have been effectively framed as part of an American system. Rightfully so, US leaders were convinced that its Allies would be more inclined to engage along the United States in such circumstances.

In Poland, that blurred perception was fostered by the events that seemed to confirm a simple continuation of the course of events from the first post-Cold War decade. That was the way Poland justified domestically its - largest since 1945 - military effort in 
Iraq and Afghanistan, or its talks concerning the positioning of a US anti-missile system in Northern Poland strongly objected by Russia and Western Europeans. In real life, they really meant quite an opposite trend (Kupiecki, 2013; Zaborowski, 2013).

\section{PERCEPTION AND CREDIBILITY}

The second layer of this asymmetry is set by the differences in defining the scope of the "hard" security interests of the two partners. The reference point here is, what seems to be obvious, the global focus of the US security policy. Its regional aspects follow the pattern built in the sequence of diversely viewed priorities, and thus determine the choice of instruments and partners - not always in line with the system of American alliances, or the views of their allies on particular matters. USA is involved in alliances with 32 nations, including 27 NATO members, Australia, Japan, the Philippines, South Korea and Thailand. Additional 10 nations (among others Israel, Egypt, Pakistan, New Zealand) are included in the group of "major non-NATO allies". Another 32 states have signed "strategic partnership" treaties with the US, or currently continue "strategic dialogue" with America. The former Secretary of Defence Donald Rumsfeld announced that "in the new century the USA have embarked on a substantial transformation of their military ties and relations, and partnerships around the world [...] The USA have never before in history been more involved in more initiatives developed jointly with a larger number of nations, and in a more constructive and more widespread way [...]. The structure and the role of our traditional alliances, NATO, for example, are subject to a revision" (Rumsfeld, 2006).

For Poland, the important parts of this issue are the possible effects stemming from the dynamics of US security policy, and from a potentially growing gap in hierarchy and geographical distribution of perceived threats. Poland gives natural priority to the regional security (in Europe) - paying particular attention to its Eastern neighborhood (Kupiecki, 2015: 68-79). Based on a current definition of national interests, capabilities, the rule of law in international relations, and the preferences for acting together with its allies, Poland also stresses its selective approach to global problems. This clash of national perspectives reflects a permanent problem in non-confrontational asymmetrical defense relations. It is defined, on one hand, by the fear of being involved in conflicts of the stronger ally, and, on the other hand, the question of solidarity of the latter when facing the threats signaled by the weaker side. The nuance in this last issue can be the question concerning the assessment of the results of the US policy in matters of key importance to Poland. Over the last two decades three questions seemed to be particularly relevant. All of them, paradoxically, are tied to some very concrete activity of the US concerning Russia.

Chronologically, the first one is the long-term consequences of unilateral military self-restrictions declared by NATO in 1996-1997. They concerned the lack of reason, plan or intention for deploying nuclear weapons on the territories of the new allies. The Alliance has also voiced pledge that: "[...] in the current and foreseeable security environment, the Alliance will carry out its collective defence and other missions by ensuring the necessary interoperability, integration and capability for reinforcement rather 
than by additional permanent stationing of substantial combat forces". This NATO declaration concerning the newly emerging NATO Eastern flank was extended to the issue of military infrastructure as well. These provisions were later repeated in the NATO - Russia Founding Act of May 1997. And just like that, they yielded a distinctive asymmetry into the collective defense mechanisms to the obvious detriment for the new members. This concerned the distribution of allied military infrastructure (bases, headquarters, and other military installations) and permanently stationing troops. For many years also the number and scale of NATO military exercises was drastically limited. For the United States that policy was actually a reaction to the end of the Cold War, but also (not reciprocated by Moscow) a sort of investment in mutual relations. Poland, together with the Alliance's legal acquis, had to accept this obligation the moment it joined NATO. This situation has been a visible proof of asymmetry in actual military status of the old vs. new NATO member states. Apart from that, it led to downsizing the military presence of the United States in Europe. An attempt to reverse this situation, at least to some extent, was visible in NATO reaction to the Russian-Ukrainian conflict.

The second problem was - mainly in 2007-2010, a whole set of issues related to the Polish-American cooperation in the field of ballistic missile defense. The asymmetry of bilateral relation was stripped down to the very core here. When signing the 2008 agreement concerning the deployment of the BMD system within its borders (with George W. Bush Administration, three months prior to the presidential elections) Poland was fully aware of the political risk it was taking. It knew that the cooperation depended entirely on the US decision. The then-Democratic presidential candidate voiced rather clearly in his campaign his intent to thoroughly revise the American plans concerning the European segment of the missile shield. This created a rather unclear, ambiguous and nervous situation, at a time when the Bush administration was approaching the end of term, and couldn't take any actual steps towards the implementation of the 2008 agreement with Poland. After presidential elections, the new Administration did not feel bound by any commitments of its predecessor and, although from a legal standpoint it was justified, it seemed non-complying with the country's obligation towards an ally.

The policy change was put into effect on September 17, 2009, induced by the analysis of the technological issues, financial calculations, and the assessment of the implications for US-Russia relations, which were to be significantly improved (reset). As for that last question - the European part of the Bush's missile defense program was viewed as a serious impediment in the Obama Russian policy ${ }^{3}$. A renown American sovietologist of Polish origin, in an interview for Polish press said that: “The White House doesn't seem to know what is doing. They give something with one hand, just to take it away with the other [...] it is very difficult to balance it properly, to support good relations with Warsaw, and at the same time to improve the contacts with Moscow. So, if Barack Obama were to

3 The Obama decisions caused a lively discussion, in Washington. These are examples of some of the leading US daily newspapers from a few days after the decision was announced: "The Washington Post": Missile Strike; Placating Russia Won't Work; Obama's Anniversary Gift to Russia; "Wall Street Journal": Cold War Lesson Lost on Obama; Obama's Missile Offense; Obama's Strategic Confusion, "New York Times": Now, Reset with the Poles, and Czechs; Ticking the Wrong Boxes; It's Better These Days to Be a US Adversary than its Friend. To some extent, these titles reflected the emotions in Poland, too. 
give up some project in Poland because Russia would object to it as an act of US interference with Russian sphere of influence, then he would do it" (Pipes, 2009).

The decisions of the newly elected president evoked a public and emotional discourse in Poland (and even more practical, yet covert mature political and diplomatic activity). The finale of the process and the fact that Poland remained a part of the American program - later transformed into European Phased Adaptive Approach - EPAA (Obama, 2009), as well as the successful negotiation of the new agreement and accompanying contracts that pushed forward the military cooperation, proves that the decisions of Polish authorities at the time were actually wise. Apart from the unpleasant feeling concerning the way the US decision (unconsulted with their allies) was made public and the ominous symbolism of the date when it happened, what prevailed was the sober and mature judgment of the national and allied interests, and the commitment to upkeep the American presence in Europe. The new program, according to President Obama, is more comprehensive than the previous program; it deploys capabilities that are proven and cost-effective; it sustains and builds upon our commitment to protect the U.S. homeland against long-range ballistic missile threats; and it ensures and enhances the protection of all NATO allies.

The third of the described issues concerns broader implications of the policy towards Russia (Stent, 2014) for the relation of the USA with their Central and East European allies. It is also rooted in the asymmetry in importance of that alliance for both sides. Washington's European policy shifts in the last twenty years have echoed widely in the countries of the region (as practical current policy assessment, and the anticipation of its long-term consequences). It was connected with anxiety that for the sake of strategic US-Russia relations the American regional alliances could be pushed into the background. In other words, there was a need to remove the fear that any reset (and, in a sense, regional pivots) of the American policy could be done at the expense of the European partners. Their effort to keep up the intensity of the relation, to fill it with practical content, military engagement out-of-area, or their strong pro-Atlanticism in NATO, were the instruments that were noticeable, also in Poland's activity towards the USA.

\section{OTHER ISSUES}

The third layer of asymmetry in Polish-American security relations concerns the quality of transatlantic cooperation in NATO. Historically, it is measured by how much (and under what conditions) would Washington be ready to sacrifice its own safety in order to actively engage and stand for Europe. This becomes more valid, specifically when the US security guarantees have to face a potential conflict with another nuclear superpower. The source of potential threat lies in Europe (or its outskirts), and relative distance and safety of the continental part of the USA shapes threat perception in Washington, differently than in European capitals. The dilemma can be fuelled by co-existence of the elements of rivalry, conflict of interests, and the need to cooperate on global issues with the mentioned superpower. In the situation when European allies remain militarily dependent on the USA, they fear that the American reaction to the threat could lack automaticity or even ignore the questions that are vital for their allies. By accepting American security guarantees, Europe also wanted to avoid being dragged into America's conflicts on the 
peripheries of the North Atlantic area. And for Washington, in need of European cooperation, but failing to see the problem of balance of power as a purely regional issue, dispelling those doubts was to prevent renationalization of the defense policies, and to curb the desire to boost their nuclear weapon arsenals. For America, the European alliances are important, but still, just one of many ways to limit the threats to their territory and to strengthen their position in the world (Snyder, 1984: 461-495).

Two American scholars, have pointed to some 31 Cold War period situations where the solidarity among NATO members was put to test. They can be ordered as five distinct recurring scenarios of permanent relevance for the question of asymmetrical security relations: 1) causing resistance from being involved into peripheral conflict of another ally; 2) evoking protest against any action by an ally violating interests of another; 3 ) connected with the resistance towards a situation when one ally called for solidarity on a worldwide scale; 4) yielding conflicts connected with the burden-sharing and the scope of reciprocal benefits; 5) evoking crucial differences in opinions regarding threats or deciding on convergence of interests resulting from the developments out-of-area (Stuart, Tow, 1990).

An integral part of this permanent (historical) NATO dilemma is a very tough question of sharing the burdens of collective defense. In American optics, after the end of the Cold War, there is no excuse for continued decrease in military spending by its European allies, and neither for the disproportionately high, exceeding $50 \%$, their own share in NATO expenses. The numbers here are rather ruthless - if in 1990 the then 16 NATO members spent 314 billion USD on defense, 20 years later 28 member states would spent 275 billion. In 2014 this amount went down to 250 billion, with just a few allies that actually allocate agreed $2 \%$ of the GDP on defense (Stoltenberg, 2014). In this argumentation what stems out, is the free rider problem, in which the American effort seem to bring more benefits to the allies, than to the USA fighting heavily to balance their state budget. In his well-known farewell address, the outgoing Secretary of Defense, being a vocal advocate of strong transatlantic link, warned us in clear terms against a threat of America losing its interest in NATO, provided that there is no substantial change in cost distribution among allies (Gates, 2011).

The cost-benefit ratio for America, resulting from their investments in transatlantic relations, has of course undergone changes in recent 70 years. But there is no doubt that we could find and point to the undeniable gains for Washington from keeping up the transatlantic bond, such as the prevention of the nuclearization of Europe, decreasing the national egoism in European defence policies, securing the influence on their foreign policy and obtaining access to their bases, what shortened the response time for threats appearing in distant operational theaters. There are also some substantial benefits connected with strengthening, at least in that segment of international relations, the legitimacy of the American power. It constitutes the essence of the transatlantic bargain, where since the 1990's Poland is one of the shareholders. Its elements are, in equal measure, the American security guarantees for Europe and the promise on the European side that these provisions would not be abused and that the allies would refrain from any potentially harmful activity for the American national interest. In such arrangement, not per se eliminating the consequences of the asymmetry, there appear rules of the game beneficial for both sides. What matters, too, are the common mechanisms of 
political coordination (a negotiated hierarchy as the acceptable alternative for the dominance and subordination) accepting agreement to disagree on various issues, understood as a safety tool for the alliance of sovereign democratic nations.

Fourth, these rules are helpful when it comes to communication in time of diverse threat perception and in search of common solutions. In effect, this problem does not always have to lead to a controversy in Polish-American relations. The experience of the last quarter of a century suggests Poland's readiness for involvement in crisis management exceeding the immediate national security interests (see: Iraq and Afghanistan, and earlier-on Haiti). The problem though, in the eyes of Washington, remains the question whether Poland can be automatically treated as an active ally in reference to any military activity involving the USA. Other more complex scenarios with no bearing on bilateral security relations are also always possible (for example military absence of Poland during the operation in Libya).

For Warsaw, the question that has to remain open is the estimate of the cost of active involvement, some limited activity (matching, or below the expectations of the United States), or refraining from involvement in a concrete situation. In the shadow of some concrete choices that are determined by the time and characteristics of a given activity - there still exists the maturity of the Polish-American relation, allowing for a more flexible and long-term assessment of available policy options. Taking into account Poland's potential and its expectations as for the American assistance in national security matters, the nation can be considered as potentially willing to take the active stand by its ally (without prejudging the final decision). And as for America, it has to be flexible when formulating its expectations, moving away from the makeshift solution (now and here) as a measure of the strength and practical utility of the alliance. Modern crises are often lengthy in nature - and thus they require a response calculated in long-term perspective. That opens a broad area for fruitful cooperation during various phases of international crisis management.

Fifth, finally, the effects of asymmetry appear also in relation to other aspects of security, defined in non-military terms (new paradigm). The consequences of differences in approach, or willingness to cooperate, may yet be different for the climate issues, cyber defence, energy security, and for the classical hard security problems. The diversity of interest and availability of broader set of policy options can lead to loosening of some dependencies, and the mechanisms characteristic for asymmetric relations in the defense area. As a result, there can be a relative growth of position for the weaker partner in terms of the expectations of the stronger side. That specifically pertains to the activity within international organizations, in general debates, or when it comes to voting. An interesting research field here is the analysis of voting patterns of the United States and its allies in the United Nations (Voting, general).

\section{CONCLUSIONS IN THE CONTEXT OF ASYMMETRY THEORY}

Regardless of interdependence and intense interaction, so characteristic of the Poland-US security and defense relations, there remains no doubt that they hold much higher value for Warsaw than for Washington and it is America that keeps a stronger 
position here. That forces Warsaw to have a more detailed insight into Washington's actions, accompanied by an effort to accommodate its position, with no guarantee whatsoever that there would be a similar response to Poland's expectations ${ }^{4}$. This model can be found in mutual relations of the two nations in the last two decades. It has resounded publicly many times in Poland, where there were attempts at assessing the Poland's revenue for the engagement in Iraq and in Afghanistan, or Poland's predisposition for hosting a US missile defense system on its territory.

Based on hard data, one could still venture a statement that Poland has obtained over the post-Cold War quarter of a century more attention from the US than any other nation in the region. In recent years, in terms of defense (except in a NATO context and the reaction to Russia-Ukraine conflict), the balance of US attention has also improved due to the improvement of Poland's defense capabilities, as well as the ambitious modernization program of the Polish Armed Forces. The cumulative defense spending growth amounting to $25 \%$ over last four years, could not have gone unnoticed, especially in contrast to the declining trend in Europe. In net terms, Poland's spendings on defense surmount those of the other 11 new NATO members combined.

The political narrative of Warsaw directed at Washington has also changed considerably - it has been highlighting for years now the efforts of Poland and mutual benefits resulting from the partner's involvement. A perfect example of such attitude is the Solidarity and Partnership program, presented in April 2014 by the Polish Minister of National Defense (Siemoniak, 2014). The program included strengthening the cooperation in major defense capabilities investment areas, which are in line with the needs of expanding defense capabilities of the whole Alliance: missile defense, army, air force and special operations forces capabilities, as well as reconnaissance, cyber and cryptology improvements. Cooperation with the USA in that matter was not strictly financial, or equipment-related, but also connected with the increased American presence in Poland (joint exercises and training, prepositioning of military equipment) and also with the readiness of the US government and industry to embark on long term cooperation in the field of defense technology in Poland.

Bilateral defense co-operation between Poland and America has been both regular and intense in recent years. The processes that accompanied it were designed to neutralize problems and to prevent their growth. Difficult relations, especially in the initial stage of the Obama Presidency, with the pivot to Asia and Russian reset in the background, in the longer run seem to have come out as better balanced. Their routine character and multiple channels of dialogue, have facilitated problem resolution and crossing over some dry patches without any substantial political costs (Transatlantic, 2015). Neutralizing controversial issues was also helped by the fact that Polish-US relations were never narrowed down to a limited spectrum of issues. By the same token, even the most controversial issue would not overthrow our two-sided relation singlehandedly.

4 One could venture here a provocative statement that mutual relation between Poland and the USA, goes in Poland far beyond politics and strategy, and is closely connected to the nation's emotions. 
Such a situation made it possible to continue and progress, wherever and whenever possible. Also, maturity and consistency in presenting the Polish standpoint, holding back public emotions and prompt, necessary adjustments of American policy, with mutual benefits for both sides have been able to even-out some formerly bumpy paths of that cooperation. Importantly, these relations have been rooted in long-established capital of reciprocal sympathy between the two societies. As for the Polish side, that aspect has always been rather typical. It is Polish political and military involvement, assistance and solidarity offered to America after 9/11 that have definitely increased the name recognition of Poland and positive attitude towards it among average Americans ${ }^{5}$ in the period of a patriotic surge across the Atlantic that constituted an important political value for Warsaw. What proved to be a real challenge was the consolidation of that capital over time.

Anyway, as the experience of real politics, and the premise of the asymmetry theory, in the type of relation described above, where reciprocity and interdependence are more of a consensus than coercion in nature, the problem of maintaining that state of relative balance remains an issue. In other words, it is not easy to uphold the stronger side's motivation to respect its own obligations. Then, if the underlying point of the "asymmetry theory" is the assumption that the relation between countries with huge difference in their potential can still develop normally, then a really interesting material for research is provided by the Polish-American relations.

\section{BIBLIOGRAPHY}

Annual Reports to the Congress on Voting Practices In the United Nations, $\mathrm{http}: / / \mathrm{www} . \mathrm{state} . \mathrm{gov} / \mathrm{p} / \mathrm{io} / \mathrm{rls} / \mathrm{rpt} / \mathrm{index} . \mathrm{htm} / \mathrm{d}$ (2.04.2015).

Asymmetry and Systemic Misperception. The Cases of China, Vietnam and Cambodia during the 1970's (2003), “Journal of Strategic Studies”, No. 2.

Asymmetry Theory and China's Concept of Multipolarity (2004), "Journal of Contemporary China”, May.

China Among Unequals. Asymmetric Foreign Relationships in Asia (2010), Singapore.

Dolan M. B., Tomlin B., Appel Molot M., Rikehoff H. (1980), Foreign Policies of African States in Asymmetrical Dyads, "International Studies Quarterly", No. 3.

Dolan M. B., Tomlin B. (1984), Foreign Policy in Asymmetrical Dyads. Theoretical Reformulation and Empirical Analysis, "International Studies Quarterly", No. 3.

Dybczyński A. (2014), Sojusze międzynarodowe (International Alliances), Warszawa.

Founding Act on Mutual Relations, Cooperation and Security between NATO and the Russian Federation signed in Paris, France, 27 May 1997, http://www.nato.int/cps/en/natohq/official_texts_25468.htm/ (2.02.2015).

Gates R. (2011), The Security and Defense Agenda. Future of NATO, http://www.defense.gov/speeches/speech.aspx?speechid+1582/ (2.01.2015).

5 In this respect the Author can provide a rather humorous example from his own experience. During the Iraq operation, when visiting Washington he was buying some small souvenirs. When asked about his country of origin, and the answer was Poland, he got immediate discount on his purchase, as a token of gratitude for Polish solidarity with America. This kind of reaction was not, in fact, unusual. I heard similar words (without any financial rewards) coming from "ordinary Americans" many times. Also during more serious, formal high-level meetings. 
How Size Matters. The United States, China and Asymmetry (2001), "Journal of Strategic Studies", No. 4.

Kupiecki R. (2013), Amerykański sen na jawie (The American Daydream), "Rzeczpospolita", 8.10.2013.

Kupiecki R. (2015), The Security Dilemmas Facing Central and Eastern Europe, NATO, the United States, and Transatlantic Security Relations, w: Transatlantic Relations in a Changing European Security Environment, (eds.) R. Kupiecki, A. A. Michta, Warsaw-Washington DC.

National Security Strategy of the Republic of Poland 2014 (2014), Warsaw.

Osica O. (2009), O stosunkach polsko-amerykańskich (On Polish-American Relations), "Nowa Europa", No. 1.

Pipes R. (2009), Rosja jest teraz dla Obamy najważiejsza (Russia is More Important Now for Obama), "Rzeczpospolita", 22.10.2009.

President G. W. Bush 2003 State of the Union Address, http://www.cnn.com/2003/ALLPOLITICS/01/28/sotu.transcript/ (2.01.2015).

President G. W. Bush 2007 State of the Union Address, http://ww.washingtonpost.com/wpdyn/content/article/2007/001/23/AR2007012301075.html/ (2.02.2015).

Remarks by the President (Obama) on the Strengthening Missile Defence in Europe, September 17, 2009, http://www.whitehouse.gov/the-press-office/remarks-president-strengthening-missile-defense-europe/d (8.02.2016).

Remarks by President Obama at $25^{\text {th }}$ Anniversary of Freedom Day, Castle Square, Warsaw, Poland, http://www.whitehouse.gov/the-press-office/2014/06/04/remarks-president-obama-25th-anniversary-freedom-day/ (12.08.2014).

Rumsfeld D. (2006), Sojusze na nowy wiek (The Alliance for a New Century), "Rzeczpospolita", 15.05.2006.

Siemoniak T. (2014), Siemoniak: obecność wojskowa USA w Polsce będzie rosnqć (Siemoniak: The US Military Presence in Poland Will Grow), "Polish Press Agency Wire", 19.04.2014.

Snyder G. H. (1984), The Security Dilemma in Alliance Politics, "World Politics", No. 4.

Stent A. (2014), The Limits of Partnership. US-Russian Relations in the Twenty-First Century, Princeton.

Stoltenberg J. (2014), The Secretary General's Annual Report 2014, http://www.nato.int/cps/ en/natohq/opinions_116854.htm (2.02.2015).

Stuart D. T., Tow W. (1990), The Limits of the Alliance. NATO Out-of-Area Problems since 1949, Baltimore.

Szklarski B. (2015), Niekonfrontacyjna asymetria $w$ relacjach polsko-amerykańskich (The Non-Confrontational Asymmetry in Poland-US Relations), Warszawa.

Transatlantic Trends (2015), http://www.trends.gmfus.org/archives/d (16.01.2016).

Wight M. (1978), Power Politics, London.

Womack B. (2006), China and Vietnam. The Politics of Asymmetry, New York.

Zaborowski M. (2013), Koniec amerykańskiego snu (The End of American Dream), "Gazeta Wyborcza", 28/29.09.2013.

Zaborowski M., Longhurst K. (2003), America's Protégé in the East? The Emergence of Poland as a Regional Leader, "International Affairs", No. 3.

\begin{abstract}
Asymmetry in inter-state relations occurs when one of the partners enjoys more freedom of action, resulting from a unique confluence of power factors, thus obtaining a dominant position.
\end{abstract}


Still, in the process, the superior power incurs costs and risks ineffectiveness, thus having to precisely calculate its modus operandi, while the weaker state has at its disposal means to mitigate the consequences of existing power discrepancies. Asymmetry defines Polish-US relations, manifesting itself with full strength in the field of security and defense, given the discrepancies in the two countries' potentials, different roles played in international relations and the position of the USA as the guarantor of Poland's security. This article touches upon the effects and the dynamics of this situation, perceived as a process that is the result of certain adjustments rather than coercion. Included in it is the ability of influencing the politics of the stronger partner as well as the overvaluation of its results by the weaker side, along with the neglect of the weaker player's interests by the dominating side. Managing this kind of relations demands maturity and loyalty on both sides. Also, necessary is the institutionalization of deconflicting the priorities of cooperation, using international law tools and consultation mechanisms offered by multilateral forums as well as negotiating mutual relations protecting from their dissolution. Not without importance are also societal sentiments, as well as respect towards all symbolism that underlines mutual relations. Key for Polish-American cooperation, in the field of security, is an understanding of the USA's global perspective, in which Europe is only one of its dimensions.

Key words: asymmetry, asymmetry theory, Poland, United States, Security, NATO, International relations

\section{TEORIA ASYMETRII A STOSUNKI POLSKA-USA W DZIEDZINIE BEZPIECZEŃSTWA}

\section{STRESZCZENIE}

Asymetria w stosunkach międzypaństwowych pojawia się, gdy jeden z partnerów dysponuje większą swobodą działania, wynikającą z nagromadzonych czynników potęgi. We wzajemnych interakcjach, strona dominująca ponosi jednak koszty oraz ryzykuje brak efektywności, stąd musi dobrze skalkulować swój sposób działania. Słabszy partner dysponuje bowiem sposobami zarządzania skutkami nierównowagi potencjałów. Asymetria definiuje stosunki polsko-amerykańskie w dziedzinie bezpieczeństwa, zważywszy różnicę potencjałów, ról w stosunkach międzynarodowych oraz pozycję USA jako gwaranta bezpieczeństwa Polski. Niniejszy artykuł podejmuje zagadnienie skutków i dynamiki tej sytuacji, jako procesu będącego raczej efektem dostosowań, aniżeli przymusu. Obecna jest w nim zarówno możliwość wpływania na politykę silniejszego partnera oraz nadwartościowanie jej skutków przez stronę słabszą, jak również lekceważenie interesów słabszego przez stronę dominująca. Zarządzanie takimi stosunkami wymaga dojrzałości i lojalności po obu stronach. Konieczna jest także instytucjonalizacja mechanizmów dekonfliktowania priorytetów współpracy, wykorzystanie narzędzi prawa międzynarodowego i mechanizmów konsultacyjnych oferowanych przez fora wielostronne oraz swoistego negocjowania wzajemnych relacji chroniącego przed ich rozpadem. Niebagatelne znaczenie odgrywają też emocje społeczne, jak również respekt dla symboliki podkreślającej wzajemne związki. Kluczowe dla polsko-amerykańskiej współpracy w dziedzinie bezpieczeństwa jest zrozumienie globalnej perspektywy USA, dla której Europa stanowi zaledwie jeden z wymiarów jej strategii.

Słowa kluczowe: asymetria, teoria asymetrii, Polska, Stany Zjednoczone, bezpieczeństwo, NATO, stosunki międzynarodowe 